\title{
Use of elements of semiotic language in tourism marketing
}

\author{
Michal Kolcun ${ }^{1, *}$, Sebastian Kot ${ }^{2}$, Iwona Grabara ${ }^{2}$ \\ ${ }^{1}$ Technical University of Košice, Bayerova 1, 08001, Prešov, Slovakia \\ ${ }^{2}$ Czestochowa University of Technology, gen. Jana Henryka Dąbrowskiego 69, Częstochowa, Poland \\ *E-mail address: mikolcun@yahoo.com
}

\begin{abstract}
Tourism marketing has developed a semiotic tourism language to promote and introduce touristic destinations, a language that is sometimes even called touristic language, and which uses signs and images to define destinations or describe the expectations that we may have in various touristic locations. The correct use of the signs and the markers by the tourism industry may represent the difference between a dreamlike holiday and a touristic nightmare, when there's no account of regional characteristics, social or cultural, of the chosen target segment.
\end{abstract}

Keywords: semiotic language; tourism; marketing; communication

\section{INTRODUCTION}

There is no communication outside the words, images, gestures or actions loaded with a certain significance. All these ways of relating are signs or markers which can represent a specifically object for a specifically interpreter. The interpreter, the third element of the semiotic triangle of Peirce (with sign and object) brings the difference between semantics and pragmatic of communicational interpretation (Tresidder, 2011; Borowski, 2014). If the semantics deals with isolated meaning of a communication, with the analysis of communication of the message itself, pragmatic analysis brings several elements that give meaning broader or entirely new of the semiotic interpretation (depending on context, time, location, cultural training, interprets, etc.). being concerned about the success or the failure of communication.

\section{SEMIOTIC LANGUAGE IN TOURISM}

Communication in tourism is essential. Sale of intangible products when purchasing requires the use of a wide range of elements of product presentation, a wide range of extremely markers that will be presented to potential tourists so that they can choose a destination in accordance with their expectations. How close or far from the truth is the image that tourists build for a chosen destination depends on the fairness, honesty and accuracy of semiotic language chosen by the bidder.

There is no tour operator that does not use even unconscious semiotic language. Not even could operate in his absence. Let's do a simple exercise of imagination and consider if 
there could be a sale of a product in the absence of semiotic language in tourism: the tourist entering the agency, leaving a certain amount of money and get out. He doesn't know where he goes or when, or how long he stay. Even in this hypothetical and absurd case we can't say that the semiotic language is missing, because when he leaves the agency, the tourist already has an image linked with a world that wants to explore, with a series of expectations, the temptation to unknown adventure, nostalgia of past experiences, or at least desire to leave anywhere and anytime. The tourist already formed his own universe populated of markers that develop his imagination. Each marker gives a special meaning to a signified object to form the universe that he wants (Avram \& Traistaru, 2014; Dima, 2013; Dima \& Man, 2013).

A correctly semiotic language is that one who permits identifying this hypothetical universe of tourist desire of de reality exploration of the universe that tourist will experience. Because of the tourism products it must be presented using a semiotic language to choose the best markers that can describe the reality of the tourism product so that the difference between real and imaginative universe to be minimal. The product should not be inundated by an avalanche of markers which can create confuse. They must be chosen optimally, meaning items that are very clear and can be answers to each step in the decisional hierarchy of the tourist (Vlăduţescu, 2013; Vlăduţescu, 2013).

Trough the tourism marketing, semiotics is based mainly on the use of images and text markers to add significance to this tourist destination and expectations that the tourist may have. A well-known example is that one presented by D. M. Cannell, more exactly that of a deserted beach with no people, cars, telegraph poles etc. This presentation has an impact very strong suggested. This "empty" peace beyond that suggest, apart from the absence of everyday items that tourists generally want to escape may represent also an area that tourists can take possession, where they can be integrated without conflict because it is of anyone. It is known that any tourist is considered differently than others, has something special that makes him unique, he usually understand quicker and better things that other "ordinary tourists" do not even notice. The presented beach transfers its uniqueness, even to the tourist, who can now populate with his own imagination. But this presentation is made by choosing a special niche from the tourist population, because for other niche can mean simply: No one is on the beach? Why? There are stones in the water ... or ... there are sharks ... or simply ... No one likes....

Once tourists begin to interpret the markers, we can consider that they become somehow semioticians, designing a universe based on their experiences and their psychological and cultural profile.

Because of that semiotic language must take into account of the psychology classes of tourists because the transmission of the message to potential tourists must to be optimal. It should be understand what is really significant for a tourist, and the semiotic analysis can reveal dominant markers based on culture and society. Images of the pyramids or the Eiffel Tower are such a dominant markers. The pictures that tourists make in front of them, turns them already in carriers of semiotic meanings, which represent already new markers.

Of course markers are not limited to text and images. The colors, music, films can be easily associated single or in combination. A short documentary film with the Eiffel tower silhouette, accompanied by a song by Edith Piaff can have a very strong impact on world exploration that a tourist is building.

As R. Tresider, D.M. Cannell noted, the semiotic interpretation of the individual takes place in his individual markers including perception, according to negotiate their own social structure and culture and finally their interpretation. It is obvious that the simply reading of a touristic lecture assume such a distinct interpretation for most of the tourists. In this process contribute the travelers experience, their expectations, their knowledge and also their emotions. 
The same marker may have different meanings for the participants in the act of travel. The picture of a rich buffet is crucial for a tourist who discovers an exceptional gastronomic universe and another meaning for those who contribute to it, while the chef looking at the image, can achieve the first time associations with products, problems of supply involved, searching through a specialist eye, looking for items that can be modified (Stavre, 2012; Smarandache \& Vlăduţescu, 2013; Smarandache \& Vlăduţescu, 2014).

Usually the first contact between a tourist and a touristic location isn't the location itself but a representation of it. The significant is rather a mental image representation and material objective is a representation of a real element, defined spatially and temporally separating real by theorized, the subject by the object (Traistaru, 2013).

For MacCannell, the tourism must be understood in terms of "cultural production" around tourist attraction. Basically, a tourist attraction has three components: an attraction, a marker, and a tourist (MacCannell identifies later this structure to that of Peirce concept of the sign, namely that something (marker), which is something (attraction) or someone (tourist)).

The most important and interesting component of a touristic attractions is the marker, without which the tourist would not only be able to recognize the attraction, but no the attraction itself could not exist.

When a marker represent an attraction, not only can replace the attraction but sometimes can override it. On a historic battlefield, for example there is nothing to see outside the markers themselves (cemeteries, monuments, etc.) looked as Mac Cannell. Marker can become an attraction in itself, and the attraction is inevitably seen as a location to be marked, and which as a sign Saussurian, exist only because it is different from any other.

Some tourist attractions would lose their tourists if they did not know that the sights are already "marked" as tourist attractions (Ţâţu \& Bărbulescu, 2007).

One of the semiotics of tourism is the dominant conventions of daily escape from the pressures of everyday life that it makes assault on tourists and makes them want to escape the constraints are being put on. Tourist destinations are enriching with the unique and the sensationalism that tourists want.

\section{CONCLUSION}

Semiotic analysis of tourism requires a new approach to tourist who generally has a bad press in general, and few defenders. Many times tourists are accompanied by bad smileys and are considered unimaginative, docile, boring and ignorant. It is why it must be developed a semiotic universe to highlight not only the tourist attractions but also tourists themselves. Structured approach to these semiotic complex processes can lead to spectacular results in the tourism industry. 


\section{References}

[1] R. Tresidder (2011). Research Themes for Tourism. Columns Design, Reading, UK, MPG Books Group.

[2] J. Culler, American Journal of Semiotics 1 (1981) 127-140.

[3] A. Borowski, International Letters of Social and Humanistic Sciences 11 (2014) 1-168.

[4] I. C. Dima; M. Man (2013). Budgeting and Management Control in Industrial Companies. Saarbrucken: LAP Lambert Academic Publishing.

[5] M. G. Păun, International Letters of Social and Humanistic Sciences 6 (2014) 42-48.

[6] Ştefan Vlăduţescu, European Scientific Journal 9(32) (2013).

[7] J. Culler (1988) Framing the Sign: Criticism and its Institutions. Basil Blackwell, Oxford.

[8] G. Dann (1996). The people of tourist brochures. In T. Selwyn (Ed.) The Tourist Image. Myths and Myth Making in Tourism (pp. 61-82). Chichester, John Wiley and Sons.

[9] Alina Ţenescu (2009). Comunicare, sens, discurs. Craiova: Editura Universitaria.

[10] Arthur Asa Berger, Semiotica 183 (2011) 105-119.

[11] Ş. Vlăduţescu, E. M. Ciupercă (2013). Next Flood Level of Communication: Social Networks. Aachen: Shaker Verlag.

[12] A. Borowski, International Letters of Social and Humanistic Sciences 3 (2013) 69-74.

[13] M. Siminică, A. Traistaru, International Journal of Education and Research 1(12) (2013).

[14] D. MacCannell (1999) The Tourist: A New Theory of the Leisure Class. Los Angeles, CA: University of California Press.

[15] Ion Stavre (2012). Internet and digital technology - influences on audiovisual communication and on teaching at master's degree level, Valencia, 2012, Published by International Association of Technology, Education and Development - ISBN: 978-84615-5563-5

[16] D. Ţâţu, R. Bărbulescu, Theoretical and Applied Economics 11 (516) (supplement) (vol2)) (2007) 189-192.

[17] Ştefan Vlăduţescu (2013). What Kind of Communication Is Philosophy. Jokull.

[18] Ioan Constantin Dima (2013). Organisational strategies - a systemic approach - on the example of the automotive industry. Saarbrucken: LAP Lambert Academic Publishing.

[19] A. Borowski, International Letters of Social and Humanistic Sciences 4 (2013) 70-74.

[20] Aurelia Traistaru, Elena Antoanela Cotoc (2013). Archiving, Keeping Records and Financial Accounting Documents. International.

[21] I. C. Dima (2013). Industrial Production Management in Flexible Manufacturing Systems. IGI Global USA.

[22] V. A. Enachescu, D. A. Hristache, C. E. Paicu, Review of Applied Socio-Economic Research 4(2) (2012) 93-96.

[23] Aurelia Traistaru (2013). The components of economic record and the research object of Accounting. European. 
[24] Ioan Constantin Dima, Ştefan Vlăduţescu (2012). Persuasion elements used in logistical negotiation: Persuasive logistical negotiation. Saarbrucken: LAP Lambert Academic Publishing.

[25] M. G. Mangra, E. A. Cotoc, A. Traistaru, Journal of Studies in Social Sciences 6(1) (2013).

[26] A. Borowski, International Letters of Social and Humanistic Sciences 2 (2014) 110-121.

[27] Dan Ionescu, International Letters of Social and Humanistic Sciences 12 (2014) 57-65.

[28] Marioara Avram, Aurelia Traistaru, International Letters of Social and Humanistic Sciences 13 (2014) 79-88.

[29] F. Smarandache, Ş. Vlăduţescu (2014). Neutrosophic Emergences and Incidences in Communication and Information. Saarbrucken: LAP Lambert Academic Publishing.

[30] Janusz Grabara, Michal Kolcun, Sebastian Kot (2014). The Role of Information Systems in Transport Logistics. International.

[31] Iulian Bitoleanu, International Letters of Social and Humanistic Sciences 9 (2014) 161-121.

[32] I. C. Dima, M. Man, Ş. Vlăduţescu (2012). The Company's Logistic Activity in the Conditions of Current Globalisation. In H. Cuadra-Montiel (Ed.), Globalization, Education and Management Agendas (pp. 263-294). Rijeka: Intech.

[33] F. Smarandache, Ş. Vlăduţescu (2013). Communication vs. Information, a Neutrosophic Solution. Neutrosophic Sets and Systems.

[34] Vladimir-Aurelian Enachescu, Journal of Community Positive Practices 13(2) (2013).

[35] V. Dragotă, M. Dragotă, L. Obreja, L. Ţâţu, A. Ciobanu, A. Racşa (2005). Abordări practice in finanţele firmei. Editura Irecson, Bucureşti.

[36] MacCannel, Dean (2000). Encyclopedia of Tourism. New York: Jafar Jafari.

[37] Dima I. C., Vlăduţescu Ş. (2013). Some consequences of the negative journalistic communication in the austerity periods. Science Series Data Report.

[38] Ştefan Vlăduţescu (2014). Eight computational-communicative operations of building information. Mitteilungen Klosterneuburg.

[39] Răzvan Bărbulescu, Romanian Economic Journal 13(36) (2010).

[40] A. Borowski, International Letters of Social and Humanistic Sciences 6 (2013) 86-90.

[41] Bianca Teodorescu, International Letters of Social and Humanistic Sciences 12 (2014) 73-78.

[42] M. Dragotă, V. Dragotă, L. Ţâţu, D. Ţâţu, Romanian Journal of Economic Forecasting 1 (2009) 76-93.

[43] Ştefan Vlăduţescu (2013). Principle of the Irrepressible Emergence of the Message. Jokull.

[44] O. Arhip (2012). Characteristics of Meta-Referential Discourse. Philologica Jassyensia.

[45] Aurelia Traistaru, Jokull 63(9) (2013) 125-135. 
[46] Ştefan Vlăduţescu, International Letters of Social and Humanistic Sciences 10(2) (2014) 100-106.

[48] I. C. Dima, M. Man (2013). Considerations on the strategy for sustainable development of companies under the conditions of current globalization. Science Series Data Report.

[49] Cerasela Vintilescu, International Letters of Social and Humanistic Sciences 13 (2014) 58-63. 